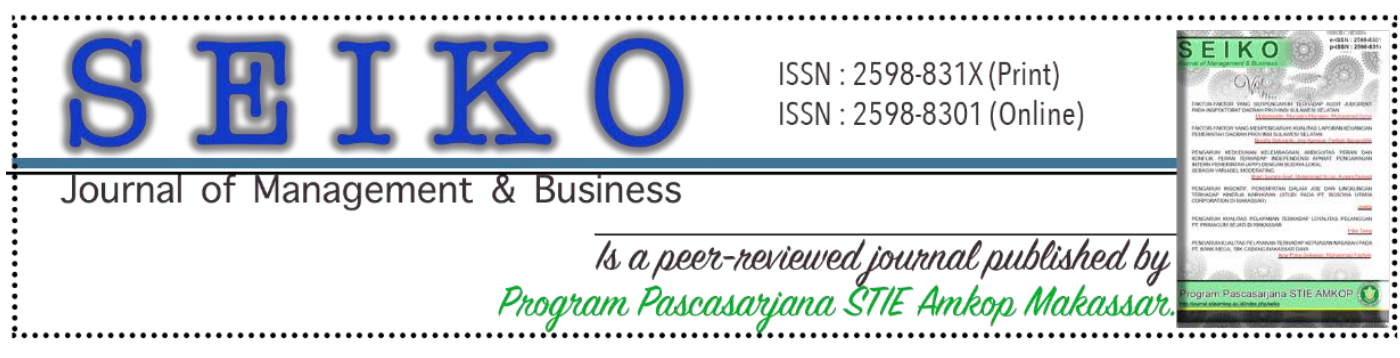

\title{
ANALISIS KINERJA PERUSAHAAN DENGAN MENGGUNAKAN PENDEKATAN BALANCED SCORECARD PADA PT. BOSOWA PROPERTINDO.
}

\author{
Analysis of Company Performance Using the Balanced \\ Scorecard Approach in Bosowa Propertindo. \\ Mukhtar Galib \\ Staf Pengajar Pada STIM Lasharan Jaya Makassar \\ Email : mukhtargalib.stimlash@gmail.com \\ Muhammad Hidayat \\ Pengajar Pada Program Pascasarjan STIE Nobel Indonesia Makassar \\ Email : hidayat2401@yahoo.com
}

\begin{abstract}
ABSTRAK
Penelitian ini bertujuan untuk : (1) Untuk mengetahui kinerja PT. Bosowa Propertindo dengan menggunakan pendekatan Balanced Scorecard (2) Penelitian ini adalah penelitian deskriptif dengan pendekatan kuantitatif dan kualitatif dengan menggunakan perhitungan melalui konsep balanced scorecard untuk masingmasing key performance indicator dalam empat perspektif bisnis balanced scorecard dengan membandingkan antara target dan pencapaiannya untuk menghasilkan nilai akhir balanced scorecard yang dicapai oleh perusahaan. Hasil penelitian ini menunjukkan : (1) Pencapaian balanced scorecard pada tahun 2017 adalah sebesar 3.195 nilai ini menunjukkan bahwa pencapaian target yang dicapai oleh perusahaan adalah lebih tinggi sedikit diatas target yang telah ditetapkan. (2) Key Performance indicator (KPI) yang ditentukan oleh PT.Bosowa Propertindo pada tahun 2017 adalah (a) Perspektif keuangan yang terdiri dari Profitability index, Return on Capital Employeed, Return on Investment, Current Ratio mencapai nilai score kumulatif balanced Scorecard sebesar 1,475 (b) Perspektif Pelanggan yang dilaksanakan dengan menganalisa kepuasan pelanggan yang terdiri dari bukti
\end{abstract}


fisik,kehandalan, daya tanggap, jaminan dan kepedulian mencapai nilai score kumulatif BSC sebesar 0,75 (c) Perspektif Proses Business internal yang terdiri dari rasio inovasi dan rasio tingkat kepatuhan mencapai nilai score kumulatif BSC sebesar 0,85 (c) Perspektif pertumbuhan dan pembelajaran yang terdiri dari kepuasan pegawai, jumlah karyawan yang mengikuti pendidikan dan pelatihan, biaya pendidikan dan pelatihan, waktu pelaksanaan.

Keyword : Kinerja, Balanced Score, PT. Bosowa

\begin{abstract}
This study aims to: (1) To determine the performance of PT. Bosowa Propertindo uses the Balanced Scorecard approach (2) This research is descriptive research with quantitative and qualitative approaches using calculations through the balanced scorecard concept for each key performance indicator in the four balanced scorecard business perspectives by comparing the targets and their achievements to produce the final value balanced scorecard achieved by the company. The results of this study indicate: (1) Achievement of the balanced scorecard in 2017 is equal to 3,195 this value indicates that the achievement of targets achieved by the company is higher slightly above the set target. (2) The Key Performance Indicator (KPI) determined by PT. Bosowa Propertindo in 2017 is (a) Financial perspective consisting of Profitability index, Return on Capital Employed, Return on Investment, Current Ratio reaches the balanced Scorecard cumulative score of 1.475 (b) The Customer Perspective carried out by analyzing customer satisfaction consisting of physical evidence, reliability, responsiveness, assurance and concern reaches the BSC cumulative score of 0.75 (c) Internal Business Process Perspective consisting of innovation ratios and compliance rate ratios achieve the BSC cumulative score of 0.85 (c) Growth and learning perspective consisting of employee satisfaction, number of employees who attend education and training, education and training costs, time of implementation.
\end{abstract}

Keyword: Performance, Balanced Score, PT. Bosowa

\title{
PENDAHULUAN
}

Pengukuran kinerja suatu perusahaan sangat berguna untuk membandingkan kinerja perusahaan periode lalu dan periode yang akan datang, sehingga dapat diketahui, kinerja mengalami perbaikan atau sebaliknya mengalami penurunan. Pengukuran kinerja merupakan usaha memetakan strategi ke dalam tindakan pencapaian target tertentu, tidak hanya target akhir yang perlu diukur dan menjadii ukuran kinerja perusahaan, tetapi juga berkaitan dengan kompetensi dan proses yang telah dilaksanakan. Selain itu, pihak manajemen juga dapat menggunakan pengukuran kinerja untuk mengevaluasi pada periode yang lalu, 
dengan dilakukan suatu tindakan yang dianggap perlu untuk memperbaikinya.

Balanced scorecard adalah alat bantu dalam melakukan penilaian kinerja yang konsepnya berupa keseimbangan antara perspektif keuangan dan perspektif non-keuangan, sebagai bagian dari strategi organisasi di masa datang. Balanced scorecard (BSC) dikembangkan untuk melengkapi pengukuran kinerja keuangan (atau dikenal dengan pengukuran tradisional) dan sebagai alat ukur yang cukup penting bagi organisasi perusahaan untuk merefleksikan pemikiran baru dalam era competitiveness dan efektivitas organisasi. Konsep ini memperkenalkan suatu sistem pengukuran kinerja perusahaan dengan menggunakan kriteria-kriteria tertentu yang merupakan penjabaran dari apa yang menjadi misi dan strategi perusahaan jangka panjang. Kriteria tersebut digolongkan menjadi empat perspektif yaitu: (1) perspektif keuangan, (2) perspektif pelanggan, (3) perspektif proses bisnis internal, dan (4) perspektif pembelajaran dan pertumbuhan. Melalui pengukuran keempat perspektif ini, manajemen perusahaan akan lebih mudah untuk mengukur kinerja dari unit bisnis saat ini dengan tetap mempertimbangkan kepentingan masa depan, mengukur apa yang telah diinvestasikan dalam pengembangan sumber daya manusia, sistem dan prosedur demi perbaikan kinerja di masa datang, serta memungkinkan untuk menilai intangible asset seperti kepuasan pelanggan, loyalitas pelanggan, dan lain-lain.(Kaplan \& Norton,1996) (Budiarti Isniar, 2009) (Srimindarti Ceacilia, 2004)

Fakta empiris di lapangan Penerapan Balanced Scorecard pada PT.Bosowa Propertindo telah berhasil dengan baik merubah perusahaan yang awalnya dikelola secara tradisional menjadi perusahaan yang modern hal ini ditunjukkan bahwa, Bosowa Corporation 30 tahun yang lalu adalah perusahaan tradisional yang hanya bergerak di bidang pembiayaan dengan CV. Moneter. Namun seiring perjalanannya Bosowa saat ini secara konsisten menerapkan Balanced Scorecard sebagai alat strategi dalam pelaksanaan formulasi implementasi dan evaluasi strateginya juga penerapan OSM (Office of strategic manajemen). Perkembangan perusahaan dapat dilihat secara empiris dari 10 tahun terakhir ini Bosowa Corporation semakin melebarkan kapasitas usahanya dan mampu mengambil alih Hotel Aryaduta Makassar, Universitas 45 Makassar, dan menjadi pemegang saham Bank Bukopin. Selain itu, Bosowa juga sudah menambah ke industri perhotelan dengan membangun Hotel Novotel Makassar, Hotel Fave Umalas Bali serta Hotel Grand 
Victoria Samarinda. Bosowa Corporation juga bekerja sama dengan Rumah Sakit Internasional dalam pendirian Rumah Sakit Awal Bros Makassar. (Razak \& Hidayat, 2016)

\section{KAJIAN PUSTAKA}

Kinerja

Pengertian kinerja atau performance merupakan gambaran mengenai tingkat pencapaian pelaksanaan suatu program kegiatan atau kebijakan dalam mewujudkan sasaran, tujuan visi dan misi organisasi yang di tuangkan melalui perencanaan strategi suatu organisasi. Moeheriono (2012) Dalam kinerja karyawan atau defisi kinerja atau performance sebagai hasil kinerja yang dapat dicapai oleh seseorang aau kelompok orang dalam suatu organisasi baik secara kualitatif maupun secara kuantitatif, sesuai dengan kewewenangan, tugas dan tanggung jawab masingmasing dalam upaya mencapai tujuanorganisasi bersangkutan secara legal, tidak melanggar hukum dan sesuai dengan moral ataupun etika. Kinerja seringkali dikaitkan dengan prestasi kerja karena pada dasarnya kinerja merupakan hasil pekerjaan seseorang yang pada akhirnya akan dipandang sebagai prestasi kerja. Untuk masalah prestasi kerja Rivai (2013) Prestasi kerja merupakan suatu fungsi dari motivasi dan kemampuan untuk menyelesaikan tugas atau pekerjaan dalam hal ini pencapain prestasi kerja seseorang dapat disebabkan karena adanya dorongan untuk berprestasi serta kemampuan seseorang dalam memahami apa yang menjadi tugas dan tanggungjawabnya. Seseorang tidak akan dapat berprestasi dengan baik apabila dia tidak memahami apa yang harus dilakukan sebagai kewajiban dan tanggungjawabnya.

\section{Pengertian Kinerja Perusahaan}

Kinerja perusahaan adalah suatu tampilan keadaan secara utuh atas perusahaan selama periode waktu tertentu, merupakan hasil atau prestasi yang dipengaruhi oleh kegiatan operasional perusahaan dalam memanfaatkan sumber daya sumber daya yang dimiliki. Kinerja atau performance merupakan gambaran mengenai tingkat pencapaian pelaksanaan suatu program kegiatan atau kebijakan dalam mewujudkan sasaran, tujuan, visi dan misi suatu organisasi yang dituangkan melalui perencanaan strategis suatu organisasl (M. Abdullah, 2014). Menurut 
Moerdiyanto (2010), mengungkapkan bahwa kinerja perusahaan adalah hasil dari serangkaian proses bisnis yang mana dengan pengorbanan beragai macam sumber daya yaitu bisa sumber daya manusia dan juga keuangan perusahaan. Apabila kinerja perusahaan meningkat, bisa dilihat dari gencarnya kegiatan perusahaa dalam rangka untuk menghasilkan keuntungan yang sebesar-besarnya. Keuntungan atau laba yang dihasilkan tentu akan berbeda tergantung dengan ukuran perusahaan yang bergerak. Berdasarkan dari proses meningkatkan penghasilan laba atau keuntungan.

\section{Pengertian Pengukuran Kinerja}

Whittaker (1993), pengukuran kinerja merupakan suatu alat manajemen yang digunakan untuk meningkatkan kualitas pengambilan keputusan dan akuntabilitas, serta untuk menilai pencapaian tujuan dan sasaran (goal sand objectives). Sedangkan menurut Moeheriono (2012), pengukuran kinerja (performance measurement) mempunyai pengertian suatu proses penilaian tentang kemajuan pekerjaan terhadap tujuan dan sasaran dalam pengelolaan sumber daya manusia untuk menghasilkan barang dan jasa, termasuk informasi atas efisiensi serta efektivitas tindakan dalam mencapai tujuan organisasi.

Dengan demikian dibutuhkan suatu pengukuran kinerja yang dapat digunakan sebagai landasan untuk menilai kemajuan yang telah dicapai dibandingkan dengan tujuan yang telah ditetapkan, sekaligus sebagai alat komunikasi dan alat manajemen untuk memperbaiki kinerja organisasi.

\section{Tujuan dan Manfaat Pengukuran kinerja}

Tujuan pengukuran kinerja adalah untuk menghasilkan data, apabila data tersebut dianalisis secara tepat akan memberikan informasi yang akurat bagi manajemen dalam pengambilan keputusan untuk meningkatkan kinerja perusahaan.

Sedangkan manfaat sistem pengukuran kinerja yang baik menurut Yuwono (2008) adalah :

1. Menelusuri kinerja terhadap harapan pelanggan sehingga akan membawa perusahaan lebih dekat pada pelanggannya dan membuat seluruh orang yang dalam organisasi terlibat dalam upaya memberikan kepuasan pelanggan. 
2. Memotivasi pegawai untuk melakukan pelayanan sebagai mata rantai pelanggan dan pemasok internal.

3. Mengidentifikasi berbagai pemborosan sekaligus mendorong upaya-upaya pengurangan terhadap pemborosan tersebut (reduction of waste).

4. Membuat tujuan strategis yang biasanya masih kabur menjadi lebih konkret sehingga mempercepat proses pembelajaran organisasi.

5. Membangun konsensus untuk melakukan suatu perubahan dengan memberi "reward" atas perilaku yang diharapkan tersebut.

\section{Karakteristik dalam Pengukuran Kinerja}

Menurut Gaspersz (2011), karakteristik yang biasa digunakan oleh organisasi kelas dunia dalam menerapkan balanced scorecard untuk mengevaluasi sistem pengukuran kinerja mereka adalah:

1. Biaya yang dikeluarkan untuk pengukuran kinerja tidak lebih besar daripada manfaat yang diterima.

2. Pengukuran harus dimulai pada permulaan program balanced scorecard. Berbagai masalah yang berkaitan dengan kinerja beserta kesempatankesempatan untuk meningkakannya harus dirumuskan secara jelas.

3. Pengukuran harus terkait langsung dengan tujuan-tujuan strategis yang dirumuskan kisi strategis dan harus memiliki paling sedikit satu pengukuran.

4. Pengukuran harus sederhana serta memunculkan data yang mudah untuk digunakan, mudah dipahami, dan mudah melaporkannya.

5. Pengukuran harus dapat diulang terus-menerus, sehingga dapat diperbandingkan.

6. Pengukuran harus dapat digunakan untuk menetapkan target, mengarah ke peningkatan kinerja di masa mendatang. .

7. Pengukuran seharusnya melibatkan semua individu yang berada dalam proses terlibat dengan program balanced scorecard.

8. Pengukuran harus akurat, dapat diandalkan, dapat diverifikasi sehingga dapat diterima dan dipercaya sebagai sahih (valid) oleh mereka yang akan menggunakannya.

9. Pengukuran harus berfokus pada tindakan korektif dan peningkatan, bukan sekadar pada pemantau (monitoring) atau pengendalian. 


\section{Pengukuran Kinerja Melalui Balanced Scorecard (BSC)}

Balanced Scorecard menurut Kaplan dan Norton (1996) adalah :

"A meassurement and management system that views a business units performance from 4 perspektif : 1) Financial 2) Customers 3) Internal Business Process 4) Learning and Growth “. (Balanced Scorecard adalah sistem manajemen dan pengaturan yang menunjukkan kinerja unit bisnis dalam empat perspektif yaitu 1) perspetif keuangan 2) pelanggan 3) proses bisnis internal 4) perspektif belajar dan bertumbuh).

Menurut Atkinson dkk (1995:445), Balanced Scorecard adalah :

A set of performance target and result that reflect the organization's performance in meeting its objective relating to its customer, employee, business partners, shareholder and community. (Balance Scorecard adalah seperangkat sasaran kinerja dan hasil yang mencerminkan kinerja perusahaan dalam mencapai tujuannya. Terkait dengan pelanggan mitrabisnis, pemegang saham dan masyarakat).

Menurut Tunggal (2001: 4) Balanced Scorecard adalah :

"Suatu sistem manajemen strategik atau lebih tepat dinamakan suatu: Strategic based responsibility accounting system "yang menjabarkan misi dan strategi suatu organisasi kedalam tujuan operasional dan tolok ukur kinerja untu 4 perspektif yang berbeda yaitu perspektif keuangan (financial perspective), perspektif pelanggan (customer perspective), perspektif proses usaha internal (internal business process perspective), perspektif pembelajaran dan pertumbuhan (learning and growth perspective)".

Menurut Chen dkk (1997) Pengertian Balanced Scorecard adalah :

A set of financial and non financial measure relating to company's critical success factors.

(Balanced Scorecard adalah seperangkat pngukuran finansial maupun non finansial yang terkait dengan faktor kritikal sukses perusahaan).

Dari definisi-definisi tersebut diatas kita dapat meyimpulkan bahwa Balanced Scorecard adalah sistem manajemen dan alat ukur kinerja perusahaan yang dilakukan dengan cara mengukur kinerja melalui empat perspektif bisnis yang meliputi aspek keuangan dan non keuangan, sistem pengukuran ini juga 
mengukur kinerja bukan hanya untuk tujuan jangka pendek dari suatu strategi perusahaan tapi juga strategi jangka panjang yang menyangkut visi dan misi perusahaan untuk dapat menciptakan suatu keunggulan daya saing.

Sebagai sistem manajemen, Balance Scorecard dapat dimanfaatkan manajemen untuk melaksanakan berbagai proses manajerial yang penting dalam organisasi yaitu :

1. Balanced Scorecard dapat digunakan sebagai alat untuk menjabarkan visi, misi serta strategi perusahaan sehingga mempermudah manajemen dalam mengarahkan perusahaan dalam mencapai tujuan.

2. Manajemen dapat mengkomunikasikan dan mengaitkan tujuan strategis dengan himpunan tolok ukur pendukungnya.

3. Manajemen dapat merencanakan, menetukan target, dan menyesuaikan inisiatif strategis.

4. Menyempurnakan umpan balik dan proses pembelajaran strategis.

BSC merupakan suatu alat pengukuran kinerja perusahaan yang mengukur kinerja perusahaan secara keseluruhan baik keuangan maupun non keuangan dengan mempertimbangkan empat aspek yang berkaitan dengan perusahaan, antara lain: aspek keuangan, pelanggan, proses bisnis internal, dan pembelajaran dan pertumbuhan. Konsep BSC berkembang sejalan dengan implementasi konsep tersebut. BSC terdiri dari dua kata: (1) kartu skor (scorecard) dan (2) berimbang (balanced). Kartu skor adalah kartu yang digunakan untuk mencatat skor hasil kinerja seseorang. Kartu skor juga dapat digunakan untuk merencanakan skor yang hendak diwujudkan oleh personel masa depan. Melalui kartu skor, skor yang hendak diwujudkan personel di masa depan dibandingkan dengan hasil kinerja sesungguhnya. Hasil perbandingan ini digunakan untuk melakukan evaluasi atas kinerja sesungguhnya.

Balanced scorecard merupakan powerfull tool dalam perencanaan strategik dan sebagai alat perencanaan. Balanced scorecard harus memiliki isi, berupa pengetahuan manajemen (management knowledge) yang bisa diimplementasikan dalam pengelolaan suatu perusahaan (Moeheriono, 2012).Sedangkan menurut Hansen dan Mowen (2011), Balanced Scorecard adalah sistem manajemen startegis yang mendefinisikan sistem akuntansi pertanggungjawaban berdasarkan strategi. 


\section{Keunggulan Balanced Scorecard}

Hasil evaluasi pengukuran kinerja berdasarkan balanced scorecard yang mencakup keempat perspektifnya baik keuangan maupun non-keuangan ternyata mampu menimbulkan rencana strategis yang bisa dirumuskan, ditetapkan dan dicapai di masa yang akan datang dalam usaha memperbaiki atau meningkatkan kinerja perusahaan. Keunggulan balanced scorecard ini tertuang dalam empat karakteristik (Mulyadi 2001) yaitu: (1) komprehensif, (2) koheren, (3) seimbang dan (4) terukur.

\section{Perspektif-Perspektif Balanced Scorecard}

\section{Perspektif Keuangan .}

Pengukuran kinerja keuangan akan menunjukkan apakah perencanaan dan pelaksanaan strategi memberikan perbaikan yang mendasar bagi keuntungan perusahaan. Perbaikan-perbaikan ini tercermin dalam sasaransasaran yang secara khusus berhubungan dengan keuntungan yang terukur, pertumbuhan usaha dan nilai pemegang saham. Perspektif ini digunakan oleh shareholder dalam rangka melakukan penilaian kinerja organisasi. Dengan kata lain organisasi harus memenuhi sebagaimana harapan shareholder agar dinilai berhasil oleh shareholder.

\section{Perspektif Pelanggan}

Dalam perspektif pelanggan balanced scorecard, perusahaan melakukan identifikasi pelanggan dan segmen pasar yang akan dimasuki. Perusahaan berusaha untuk mengetahui apa yang diharapkan pelanggan terhadap perusahaan dan bagaimana pelanggan melihat perusahaan itu sendiri. Berkaitan dengan perspektif pelanggan berarti berkaitan pula dengan kepuasan pelanggan tersebut.Sedangkan pengertian dari kepuasan pelanggan itu sendiri menurut Philip Kotler yaitu "Membuat pelanggan merasa puas berarti membangun loyalitas pelanggan, dimana hal tersebut bukan merupakan hal yang mudah untuk dilakukan." Konsep balanced scorecard, terdapat dua kelompok tolok ukur yang dapat digunakan untuk mengukur perspektif 
pelanggan yaitu customer core measurement dan customer value preposition.

\section{Perspektif Proses Bisnis Internal}

Perspektif proses bisnis internal merupakan serangkaian aktivitas yang ada dalam organisasi untuk menciptakan kualitas produk/jasa dalam rangka memenuhi harapan pelanggan.

Moeheriono (2012), pendekatan balanced scorecard dalam perspektif proses bisnis internal berfokus pada tiga proses utama, yaitu :

a. Proses Inovasi (Innovation process), mengidentifikasi karakteristik segmen pasar yang ingin dipuaskan melalui produk dan jasa perusahaan dimasa depan.

b. Proses operasi (Operations process), merupakan upaya pemenuhan kebutuhan produk dan jasa kepada pelanggan secara efisien, konsisten, dan tepat waktu.

c. Layanan purna jual (Postrable service process), merupakan upaya pemberian manfaat tambahan kepada pelanggan berupa garansi, aktivitas perbaikan dan pemrosesan pembayaran. Ketiga proses yang dinamakan "General Value Chain Model" dapat dilihat pada gambar berikut:

\section{Perspektif Pembelajaran dan Pertumbuhan}

Perspektif pembelajaran dan pertumbuhan menggambarkan kemampuan organisasi untuk melakukan perbaikan dan perubahan dengan memanfaatkan sumber daya internal organisasi. Betapa pentingnya suatu organisasi bisnis untuk terus memperhatikan karyawannya, memantau kesejahteraan karyawan dan meningkatkan pengetahuan karyawan dalam peningkatan kemampuan untuk ikut berpartisipasi mencapai tujuan perusahaan.

Menurut Tunggal (2009), terdapat tiga faktor yang perlu diperhatikan dalam melakukan pengukuran, yaitu :1) Kemampuan Karyawan (Employee Capabilities). karena itu perusahaan harus melakukan perbaikan terusmenerus.2) Kemampuan Sistem Informasi (Information System Capabilities). Dalam persaingan bisnis yang ketat maka diperlukan informasi yang tepat, cepat dan akurat sebagai umpan balik. Informasi tersebut dapat berupa informasi tentang pelanggan, proses bisnis internal, keuangan dan keputusan yang dibuat 
karyawan.

3) Motivasi, pemberdayaan dan keselarasan (Motivation, Empowerment, and alignment).

\section{METODE PENELITIAN}

Penelitian ini adalah penelitian deskriptif analistis dengan pendekatan kualitatif dan kuantitatif analisa kualitatif dilakukan untuk mendeskripsikan hasil penelitian secara terinci yang akan memberikan gambaran hasil penelitian secara faktual dan akurat sedangkan analisa kuantitatif dalam penelitian ini dilakukan melalui perhitungan-perhitungan angka angka yang ada dalam tiap-tiap perspektif balancesd scorcard untuk menganalisa antara target yang telah ditetapkan dengan pencapaiannya

\section{Metode Analisis}

pengukuran kinerja melalui pendekatan Balancedd Scorecard adalah pengukuran kinerja yang bersifat komperehensif yang dilaksanakan dengan memperhatikan corporate plan secara menyeluruh, komponen serta tolak ukur yang digunakan diformulasikan sedemikian rupa yang mengaitkan antara visi dan misi perusahaan yang dijabarkan dalam segi operasional serta penentuan tolak ukur pencapaiannya, untuk itu urutan perancangan sistem pengukuran kinerja hingga pada tolok ukur pencapaiannya serta score-score yang dihasilkan dalam sistem tersebut digambarkan melalui :

\section{1) Key Performance Indicators/KPI)}

Key Performance dari perspektif keuangan Meliputi Profitability index, return On Capital Employed, Return On Investment, dan Current Rasio analisis atas indikator indikator kinerja keuangan tersebut diukur melalui rumus-rumus yang berlaku secara umum dalam penghitungan analisa keuangan. Key Performance Indicator dari Perspektif Customer dilihat dari tingkat kepuasan pelanggan. Key Performance Indicator dari Perspektif Internal Business Proces meliputi rasio inovasi dan rasio kepatuhan dan Key Performance Indicator dari Perspektif Learning and Growth meliputi analisa terhadap kepuasan pegawai, jumlah karyawan 
yang mengikuti pelatihan, waktu pelaksanaan pelatihan, biaya pendidikan dan pelatihan, ketersediaan informasi, ketepatan informasi dan kecepatan informasi

\section{2) Target pencapaian KPI}

Terget ini adalah target yang ditentukan oleh perusahaan dalam business plan

\section{3) Realisasi Pencapaian KPI}

Realisasi KPI adalah realisasi atas KPI yang tercapai oleh perusahaan

\section{4) Penilaian Akhir}

Penilaian akhir dari Balancedd scorecard dilakukan melalui tahapan-tahapan Pembobotan untuk masing-masing perspektif, pembobotan ini ditetapkan sesuai dengan tingkat kebutuhan perusahaan berdasar pada strategi yang diambil oleh perusahaan saat periode balanced scorecard dilaksanakan

Tabel 1 Form Penilaian Akhir Pencapaian Balanced Scorecard

\begin{tabular}{|c|c|c|c|c|c|c|c|}
\hline \multirow[t]{8}{*}{$\begin{array}{l}\mathbf{N} \\
\mathbf{O}\end{array}$} & \multirow[t]{2}{*}{$\begin{array}{c}\text { Perspe } \\
\text { ktif }\end{array}$} & \multirow[t]{2}{*}{$\begin{array}{c}\text { Bobot } \\
\text { (3) }\end{array}$} & \multicolumn{4}{|c|}{$\begin{array}{l}\text { KPI } \\
(4)\end{array}$} & \multirow{2}{*}{$\begin{array}{c}\text { Score } \\
\text { (5) } \\
(3) \times(4)\end{array}$} \\
\hline & & & & $B$ & $\mathrm{~N}$ & $\mathrm{~N} \times \mathrm{B}$ & \\
\hline & & & $\begin{array}{l}\text { Profitability } \\
\text { Index }\end{array}$ & & & & \\
\hline & & & Tingkat & & & & \\
\hline & & & $\begin{array}{l}\text { Pengembali } \\
\text { an }\end{array}$ & & & & \\
\hline & & & $\begin{array}{l}\text { Investasi } \\
\text { (ROCE) }\end{array}$ & & & & \\
\hline & & & Return on & & & & \\
\hline & & & Investment & & & & \\
\hline
\end{tabular}


"VOL. 2 NO. 12018

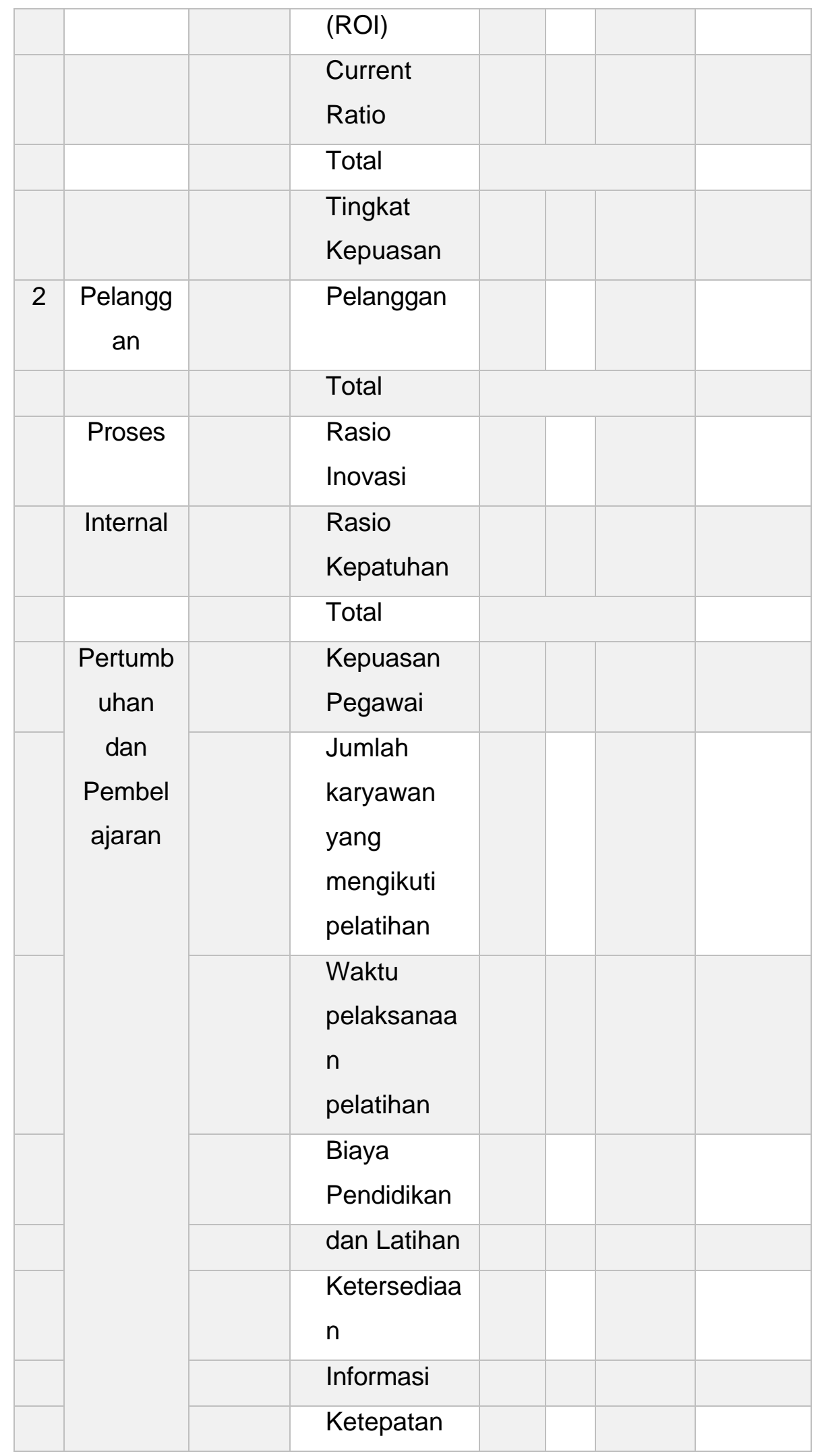




$$
\begin{aligned}
& \text { Informasi } \\
& \text { Kecepatan } \\
& \text { Informasi } \\
& \text { Total }
\end{aligned}
$$

\section{NILAI TOTAL BALANCED SCORECARD}

Sumber : Business Development Menara Bosowa

Penentuan nilai Balanced Scorecard diukur melalui standar penilaian sebagai berikut :

Tabel 2. Tabel Penilaian Balanced Scorecard

\begin{tabular}{llc}
\hline Nilai & \multicolumn{1}{c}{ Deskriptif } & Presentasi \\
\hline $\mathbf{5}$ & Pencapaian Melebihi diatas Target & $>130 \%$ \\
\hline $\mathbf{4}$ & Lebih Sedikit dari Target & $111 \%-130 \%$ \\
\hline $\mathbf{3}$ & Hampir Sesuai dengan Target & $91 \%-110 \%$ \\
\hline $\mathbf{2}$ & Tercapai Minimum Target & $80 \%-90 \%$ \\
\hline $\mathbf{1}$ & Kurang atau Sangat Jauh dari Target & $<80 \%$ \\
\hline
\end{tabular}

\section{Hasil Penelitian}

\section{Target Pencapaian Key Performance Indicator}

Analisa terhadap data-data penelitian dalam kerangka Balanced scorecard dimulai dengan melihat Penetapan Key performance Indikator (KPI) oleh PT Bosowa Propertindo yang tercantum didalam dokumen Business Plan sebagai target bisnis untuk masing-masing perspektif bisnis perusahaan. Penetapan target Key performance Indikator untuk masing-masing perspektif balanced scorecard pada PT Bosowa Propertindo adalah sebagai berikut :

Tabel 3. Penentuan Target Key Performance Indicator

\begin{tabular}{llll} 
No & Perspektif & KPI & Target \\
\hline
\end{tabular}




\begin{tabular}{|c|c|c|c|}
\hline \multirow[t]{6}{*}{1} & Perspektif & - Profitabily index & $2,5 \%$ \\
\hline & Keuangan & - $\quad$ Return On Capital & $50 \%$ \\
\hline & & Employed (ROCE) & \\
\hline & & - $\quad$ Return On & $30 \%$ \\
\hline & & Investment (ROI) & $1,5 \%$ \\
\hline & & - $\quad$ Current Ratio (CR) & \\
\hline & Perspektif & Tingkat kepuasan & 4 \\
\hline 2 & Pelanggan & pelanggan. & \\
\hline 3 & Perspektif & Rasio Inovasi & 0,2 \\
\hline & Proses Bisnis & & \\
\hline & Internal & Rasio Tingkat Kepatuhan & 0 \\
\hline \multirow[t]{11}{*}{4} & Perspektif & a. Kepuasan Pegawai & 4 \\
\hline & Pembelajaran & b. Pendidikan dan & $20 \%$ \\
\hline & dan & Pelatihan & 6x1 Tahun \\
\hline & Pertumbuhan & c. Waktu Pelaksanaan & \\
\hline & & Pelatihan & p.100.000.000 \\
\hline & & d. Biaya Pendidikan dan & Juta/Tahun \\
\hline & & Pelatihan & 4 \\
\hline & & e. Rasio Ketersediaan & \\
\hline & & Informasi & 4 \\
\hline & & f. Ketepatan Informasi & 4 \\
\hline & & g. Kecepatan Informasi & \\
\hline
\end{tabular}

\section{Pencapaian Target Key Performance Indicator}

Analisa terhadap pencapain target Key performance indicator dilakukan dengan cara menentukan gradasi yang dihasilkan dari perbandingan antara target Key performance Indicator dengan realisasi pencapaiannya. nilai gradasi tersebut akan menjadi penenti nilai dengan ukuran seperti yang telah disampaikan dalam tabel penilaian capain Balanced Scorecard (lihat Tabel 2)

Hasil analisa terhadap data-data penelitian menghasilkan nilai pencapaian 
"VOL. 2 NO. 12018

target Key Performance indicator sebagai berikut :

Tabel 4. Pencapaian Target Key Performance Indikator

\begin{tabular}{|c|c|c|c|c|c|c|}
\hline $\mathbf{N}$ & $\begin{array}{c}\text { Perspekt } \\
\text { if }\end{array}$ & KPI & $\begin{array}{c}\text { Capaian } \\
\text { Target }\end{array}$ & $\begin{array}{l}\text { Target } \\
\text { yang }\end{array}$ & $\begin{array}{c}\text { Grada } \\
\text { si }\end{array}$ & $\begin{array}{c}\text { Nila } \\
\text { i }\end{array}$ \\
\hline \multirow[t]{4}{*}{1} & Keuanga & Profitability Index & $3,01 \%$ & $2,5 \%$ & $120 \%$ & 4 \\
\hline & $\mathrm{n}$ & ROCE) & $66 \%$ & $50 \%$ & $132 \%$ & 5 \\
\hline & & ROI & $41 \%$ & $30 \%$ & $137 \%$ & 5 \\
\hline & & Current Ratio & $1,85 \%$ & $1,5 \%$ & $123 \%$ & 4 \\
\hline \multirow[t]{3}{*}{2} & Pelangga & Tingkat Kepuasan & 4 & 4 & $100 \%$ & 3 \\
\hline & Próses & Rasion Inovanasi & $0,3 \%$ & $0,2 \%$ & $150 \%$ & 4 \\
\hline & Business & Rasio Kepatuhan & $0,025 \%$ & 0 & $250 \%$ & 5 \\
\hline \multirow[t]{7}{*}{4} & Pertumbu & Kepuasan Pegawai & 5 & 4 & $125 \%$ & 4 \\
\hline & $\begin{array}{l}\text { han } \\
\text { dan }\end{array}$ & $\begin{array}{c}\text { Jumlah karyawan } \\
\text { yang mengikuti }\end{array}$ & $37 \%$ & $20 \%$ & $185 \%$ & 5 \\
\hline & Pembelaj & Biaya pendidikan & 177.500 .00 & 100.00 & $178 \%$ & 5 \\
\hline & & $\begin{array}{c}\text { dan pelatihan } \\
\text { waktu Pendidikan }\end{array}$ & $\begin{array}{c}0 \\
7 \times 1 \text { Tahun }\end{array}$ & $\begin{array}{c}0.000 \\
6 \times 1\end{array}$ & $117 \%$ & 4 \\
\hline & & $\begin{array}{c}\text { dan Latihan } \\
\text { Ketersediaan }\end{array}$ & 5 & $\underset{4}{\text { Tahun }}$ & $125 \%$ & 4 \\
\hline & & $\begin{array}{c}\text { Informasi } \\
\text { Ketepatan Informasi }\end{array}$ & 5 & 4 & $125 \%$ & 4 \\
\hline & & Kecepatan & 4 & 4 & $100 \%$ & 3 \\
\hline
\end{tabular}

Dari tabel pencapaian Target Key performance indicator tersebut diatas terlihat bahwa dari sisi financial dari empat indikator yang diukur dua indikator mendapatkan nilai 5 (jauh melampau target) yaitu ROCE dan ROI sedangkan dua indikator lainnya mendapatkan nilai 4 (Melampaui target) yaitu Profitability Index dan Current Ratio. dari hasil ini menunjukkan bahwa dari sisi keuangan perusahaan telah mencapai kinerja keuangan yang baik. Untuk perspektif pelangga 
mendapatkan nilai 3 yang berarti mencapai target. hal ini menunjukkan bahwa perusahaan telah mencapai target yang sama dengan hasil akhirnya yaitu pada tingkat puas. Untuk pencapaian nilai pada perspektif Proses Business Internal yang diukur melalui dua indikator yaitu rasio inovasi dan rasio tingkat kepatuhan menghasilkan nilai untuk rasio inovasi telah melampaui target hal ini menunjukkan bahwa perusahaan telah melakukan inovasi-inovasi yang baik. kemudian untuk rasio kepatuhan pegawai mendapatkan nilai 5 yang berarti jauh melampaui target. hal ini menunjukkan bahwa para pegawai pada PT.Bosowa Propertindo telah menjalankan tugas dan tanggungjawabnya dengan sangat baik.

Pencapain target pada Perspektif pertumbuhan dan pembelajaran menunjukkan data bahwa kepuasan pegawai mencapai nilai 4 yang berarti melampaui target hal ini menunjukkan bahwa pegawai telah merasa puas dengan perusahaan, kemudian untuk karyawan yang mengikuti pelatihan mendapatkan nilai 5 yang berarti jauh melampaui target hal ini menunjukkan bahwa perusahaan memiliki komitmen yang sangat tinggi dalam pengembangan sumberdaya manuisa yang dimilikinya hal ini sejalan dengan indikator pada biaya pendidikan dan pelatihan yang juga mendapatkan nilai 5 yang berarti jauh melampaui target. untuk tiga indikator yaitu waktu pelatihan, ketersediaan informasi dan ketepatan informasi mendapatkan nilai 4 yang berarti telah melampaui target yang ditentukan oleh perusahaan.indikator atas kecepatan informasi mendapatkan nilai 3 yang berarti kecepatan informasi sudah mencapai target namun masih perlu untuk lebih ditingkatkan kembali

Tabel 5. Score Akhir Nilai Balanced Scorecard PT.Bosowa Propertindo

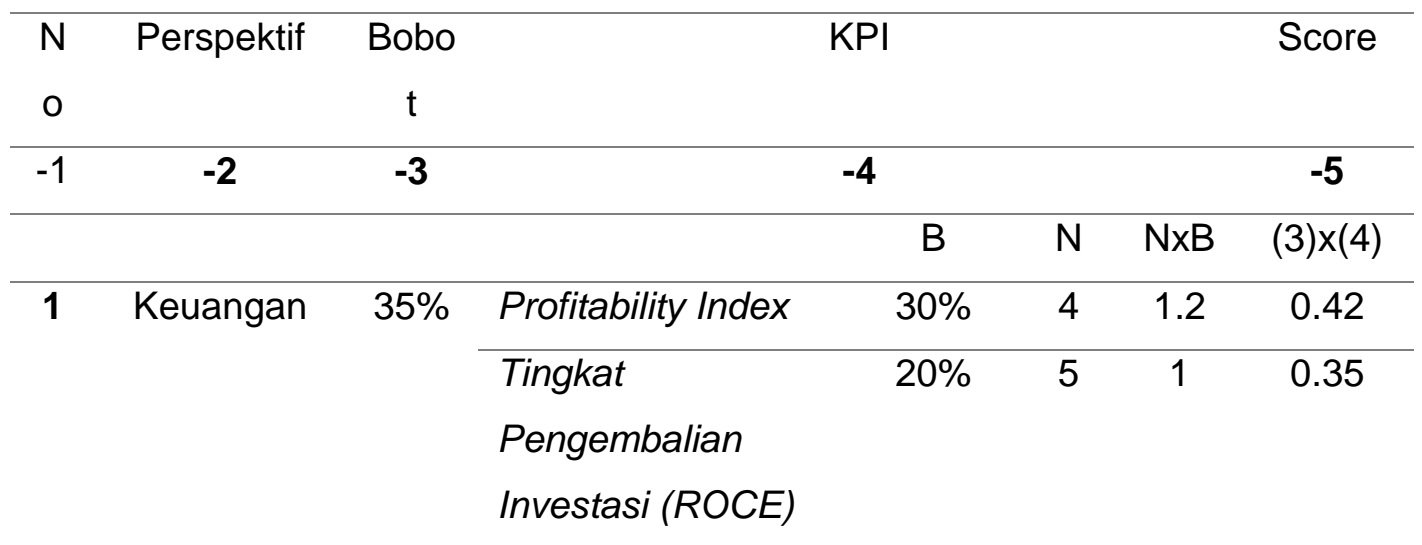


"VOL. 2 NO. 12018

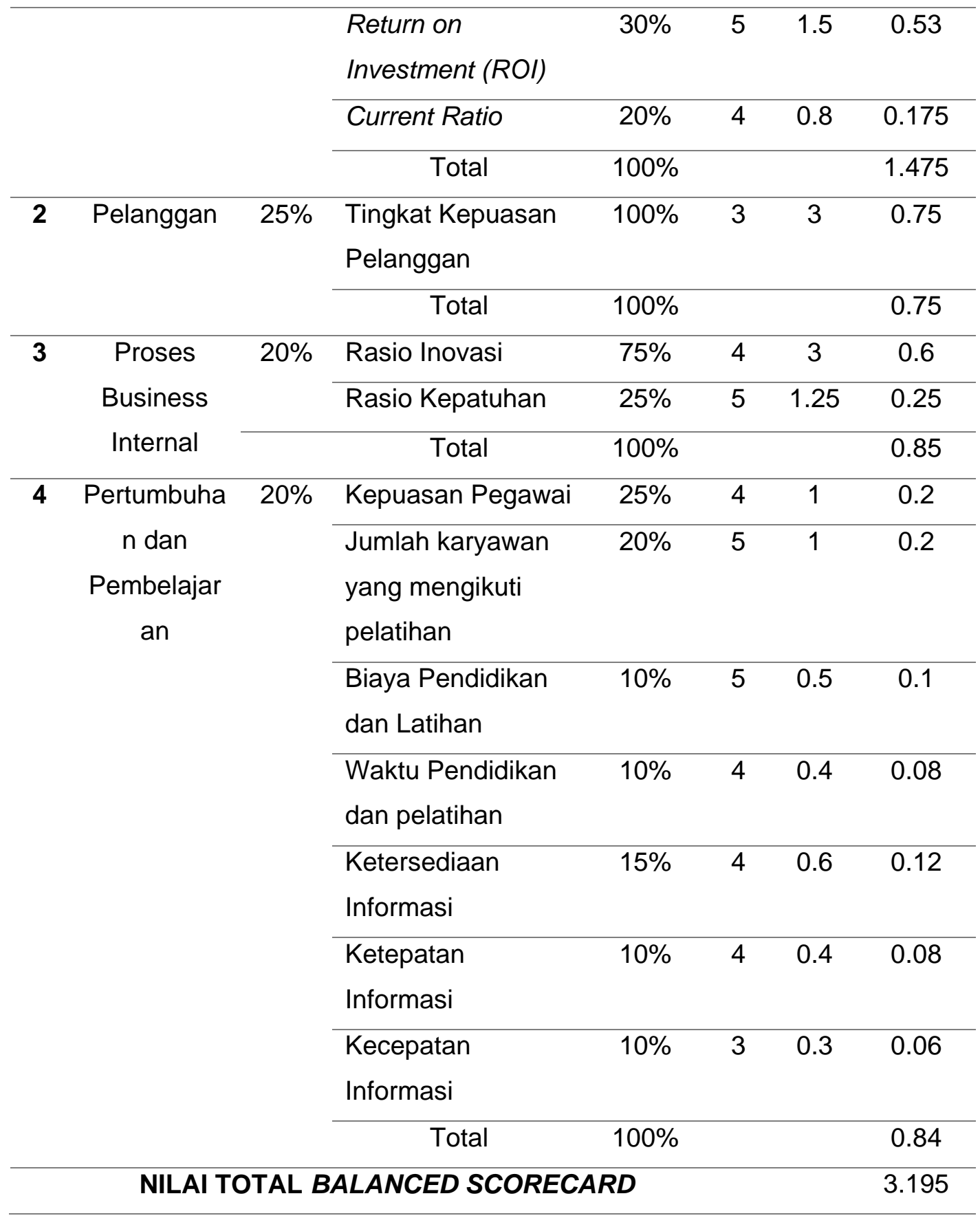

\section{PEMBAHASAN}

Rintisan penerapan Balanced Scorecard pada PT Bosowa Propertindo sudah dimulai sejak digulirkannya reformasi manajemen perusahaan pada tahun 2006. dengan mengusung transformasi manajemen dari manajemen family tradisional menuju manajemen modern Perusahaan mengawali transisi tersebut melalui 
program yang mereka namakan BUMS (Bosowa Umbrella Management System) sejak saat itu strategi perusahaan sudah mulai bercirikan Balanced Scorecard mulai dari perencanaan strategi, implementasi strategi dan evaluasi strategi

Hasil penelitian ini menunjukkan bahwa penerapan konsep Balanced Scorecard telah mengantarkan perusahaan dapat berproses dengan baik hal ini tergambar dari hasil pencapaian nilai akhir balanced scorecard pada level 3,195 nilai ini ada pada kriteria kinerja telah mencapai standar target yang telah ditentukan oleh perusahaan. fakta empiris juga membuktikan bahwa prinsip-prinsip pengukuran kinerja melalui balanced scorecard telah terinternalisasi dengan baik pada organisasi dan anggota organisasi sehingga hal tersebut menjadi penanda keefektivan penarapan strategi pengukuran kinerja melalui konsep Balanced Scorcard pada PT.Bosowa Propertindo.

\section{SIMPULAN}

1. Penelitian ini membuktikan bahwa pencapaian Kinerja PT Bosowa Propertindo yang diukur menggunakan pendekatan Balanced Scorecard, dilihat dari pencapaian kinerja untuk masing-masing perspektif, PT.Bosowa Propertindo telah mencapai target yang telah ditentukan oleh Manajemen.

2. Hasil penelitian ini menunjukkan pencapaian score akhir Balanced Scorecard tercapai pada level 3,195 yaitu pada kriteria kinerja telah tercapai sesuai dengan target yang telah ditentukan oleh perusahaan.

3. Hasil penelitian ini membuktikan bahwa pengukuran kinerja melalui konsep Balanced Scorecard dapat memberikan informasi yang komperehensif tidak hanya dari sisi keuangan tetapi juga dari sisi operasional yang pada kenyataannya adalah pemacu keberhasilan dari pencapaian kinerja keuangan itu sendiri yang berguna bagi manajemen sebagai feedback yang penting dalam penyusunan target-target bisnis pada masa yang akan datang 


\section{Referensi :}

Abdullah, M. 2014. Manajemen dan Evaluasi Kinerja Karyawan. Yogyakarta: Aswaja Pressindo.

Amin Widjaja Tunggal, (2009), Balanced Scorecard Mengukur Kinerja Bisnis. Jakarta: Harvarindo.

Atkison, Antony A, Rajiv D. Banker, Robert S. Kaplan and Mark Young. 1995. 1st ed. Management Accounting. Englewood Cliff. New Jerse. Prantice Hall.Inc.

Budiarti Isniar 2009. Pentingnya Pengukuran Kinerja Melalui Pendekatan Balanced Scorecard. Jumal IImiah Pendidikan Ekonomi Akuntansi. Vol. 3 No. 1 Januari 2009.

Chen, S.H., Yang C, Chow \& Shiau, J.Y. 2006. The Application Of Balanced Scorecard In The Performance EvaluationOf Higher Education. The TQM Magazine. 18(20, 190-205 DOI:10.1108/09544780610647892.

Gaspersz, V., 2011, Ekonomi Manajerial, Vinchristo, Bogor

Kaplan, Robert S. and David P. Norton. Balanced Scorecard: Translating Strategy into Action. Terjemahan Bahasa Indonesia. Penerbit Erlangga. 1996.

Kaplan, Robert S dan David P Norton The Balanced Scorecard Translating Strategy into Action, Harvard Business School Press, Boston, Massachusetts. 1992.

Mulyadi. 2001. Sistem Akuntansi Edisi Tiga. Jakarta. Salemba Empat.

Moerdiyanto. 2010. Pengaruh Tingkat Pendidikan Manajer terhadap Kinerja Perusahaan Go Public (Kasus BEl). Cakrawala Pendikakan. 2011. ISSN: 0216-1370.

Moeheriono. 2012. "Pengukuran Kinerja Berbasis Kompetensi" Jakarta Raya Grafindo Persada. 
Moeheriono,(2012),1ndikator Kinerja Uta Pengembangan (IKU) : Perencanaan, Aplikasi dan Pengembangan. Jakarta : Rajawali Pers.

Mashur Razak. Muhammad Hidayat. 2016. Developing The Office Of Strategic Management As A Tool To Support The Implementatrion Of Balanced Scorecard In Bosowa Corporation. American Journal Of applied Sciences. 2016, 13 (11) DOI: 10.3844/ajassp.2016.1315.1325.

Rivai, Veithzal. 2013. Manajemen Sumber Daya Manusia untuk Perusahaan: Dari Teori ke Praktek. Jakarta: Rajawali Pers

Srimindarti Ceacil 2004. Balanced Scorecard Sebagai Altematif untuk Mengukur Kinerja. Fokus Ekonomi. Vol. 3, No. 1, April.

Yuwono, Sony, 2008 Petunjuk Praktis Penyusunan Balanced Scorecard: Menuju Organisasi Yang Berfokus Strategi. Jakarta: Gramedia Pustaka Utama.

Whittaker, James, 1993. The Government Performance Result Act,Educational Services Institute. 